\title{
RETENTION AND MOBILITY OF CATIONS IN A SMALL PEATLAND: TRENDS AND MECHANISMS
}

\author{
N. R. URBAN \\ Lake Research Laboratory, EAWAG, CH-6047 Kastanienbaum, Switzerland \\ E. S. VERRY
}

U.S. Forest Service, North Central Forest Experiment Station, Grand Rapids, MN 55744, U.S.A.

and

S. J. EISENREICH

Gray Freshwater Biological Institute, Navarre, MN 55392, U.S.A.

(Received August 3, 1993; accepted July 13, 1994)

\begin{abstract}
Inputs and net storage or release of cations can have a large impact on the acid-base balance of any ecosystem. Because of the absence of mineral soils, ion exchange and accretion in biomass are the major internal processes governing cation accumulation in peatlands. It is widely believed that peatlands have a large capacity to store cations, and thus to affect the acidity of surface waters. A long-term record of hydrologic and chemical inputs and outputs to the S-2 peatland in the Marcell Experimental Forest was used to construct annual and monthly mass balances for the four major cations. Bulk deposition and throughfall measurements suggest that deposition of $\mathrm{Na}, \mathrm{Ca}$ and $\mathrm{Mg}$ has increased over the period 1971-1984; wet-only and dry bucket measurements do not show such a change. Seasonal and annual variations in cation inputs are not visible in the cation export from the peatland because the large cation reservoir on exchange sites in peat buffers the surface waters and prevents them from responding rapidly to changing inputs. Nevertheless, ion exchange represents a relatively minor source of acidity to this peatland, and accumulation of cations in woody biomass accounts for the majority of the cation retention. The major mechanism of retention in the peatland is different for each cation; accumulation in woody biomass is most important for $\mathrm{Ca}$, storage on ion exchange sites in peat is most important for $\mathrm{Mg}$, green plant tissues are the dominant site of $\mathrm{K}$ storage, and $\mathrm{Na}$ is bound by unknown mechanisms in the peat. Retention efficiencies show large annual variations but average $50 \%$ for $\mathrm{Ca}, 22 \%$ for $\mathrm{Mg}, 29-44 \%$ for $\mathrm{Na}$, and $21 \%$ for $\mathrm{K}$.
\end{abstract}

\section{Introduction}

Wetlands often have an influence on streamwater and lake chemistry that is disproportionately large relative to the fraction of the catchment that they occupy (e.g., Gorham et al., 1986; Engstrom, 1987; Johnston et al., 1990). Effects of wetlands include release of organic acids (e.g., Hemond, 1980; McKnight et al., 1985; Gorham et al., 1986; Engstrom, 1987; Urban et al., 1989a), uptake of $\mathrm{NO}_{3}^{-}$and $\mathrm{SO}_{4}{ }^{2-}$ (Hemond, 1980; Bayley et al., 1986; Bayley and Schindler, 1987; Urban et al., 1989b,c), sequestering of metals (e.g., Henrot and Wieder 1990), uptake of nutrients and cations (e.g., van der Valk et al., 1978; Tilton and Kadlec, 1979; Johnston et al., 1984), and conversion of inorganic $\mathrm{N}$ and $\mathrm{P}$ to organic forms (Devito et al., 1989). Peatlands long have been perceived as cation traps, and the acidity of bogs has been attributed to cation uptake via ion exchange (e.g., Skene, 1915; Baas Becking and Nicolai, 1934; Clymo, 1963, 1964; Andrus, 1986). Our ability to 
model and predict stream- and lakewater chemistry within catchments containing peatlands requires an understanding of the processes occurring within peatlands themselves.

As a result of internal processes, wetlands themselves may undergo acidification. The evolution of circumneutral peatlands (fens) to an acidic (bog) state is a well known paradigm (e.g., Bellamy and Rieley, 1967; Gorham et al., 1987). Recent work has demonstrated that succession is not necessarily unidirectional, but that fens can also succeed bogs (e.g., Glaser and Janssens, 1986). Acidification involves a reduction in inputs of alkaline-rich groundwater or runoff from mineral soils either because of an accumulation of organic matter that impedes such water flow (e.g., Bellamy and Rieley, 1967) or because of changes in regional groundwater flow paths or rates (Siegel, 1983). When the rate of production of organic acids within the peatland exceeds the rate of input of alkalinity, the $\mathrm{pH}$ shifts rapidly to the bog regime (i.e., $\mathrm{pH} 3.5-4.5$ ). Concomitant with this acidification, the base saturation of the peat decreases from 50-70\% to 5-30\% (e.g., Gorham et al., 1984, 1987). The reduction in base saturation may involve both stripping of cations from existing peat or merely the accumulation of new peat with low base cation content. Stratigraphic studies (Glaser and Janssens, 1986; Gorham et al., 1987) have shown that this transition in base saturation and $\mathrm{pH}$ can occur relatively rapidly (10100 yrs). There has long been concern that anthropogenic acid deposition may accelerate this process (Gorham et al., 1984). Such accelerated acidification has been demonstrated both experimentally (Bayley et al., 1986, 1987; Urban and Bayley, 1986) and in areas of intense acid deposition (Skiba et al., 1989; LaZerte, 1993).

Acidification of peatlands or of any ecosystem is dependent on the balance between inputs of acids and bases as well as on internal processes. Analysis of long-term records has revealed a steep decline in atmospheric deposition of base cations in both Europe and North America (Hedin et al., 1994). Long-term monitoring at Hubbard Brook, New Hampshire has revealed a decreased export of base cations over the past $25 \mathrm{yr}$ that has been attributed both to decreased atmospheric deposition of base cations (Driscoll et al., 1989) and to depletion of internal pools of cations (Kirchner, 1992). There are few long-term records of atmospheric deposition within the U.S.; hence it is not known if changes in deposition of base cations are widespread. Marcell Experimental Forest in Minnesota represents one of the few sites with measurements of streamflow chemistry extending back over $30 \mathrm{yr}$ and measurements of atmospheric deposition extending back $20 \mathrm{yr}$ that allow assessment of such trends.

Although the distribution of cations in peatlands has been well studied, relatively little is known about cation fluxes within or into and out of peatlands. Cation abundances are related to such factors as proximity to oceans, rates of acid deposition, extent of groundwater or upland runoff inputs, water flow rates, and proximity to agricultural areas or roads (e.g., Malmer, 1962, 1988; Comeau and Bellamy, 1986; Damman, 1987, 1986; Santelmann and Gorham, 1988; Grigal, 1991). Such studies 
imply a relationship between inputs and retention of cations, but this relationship remains unclear (Boatman et al., 1975; Damman, 1986; Malmer, 1988). Species composition of peatland floras is intimately linked with cation availability (e.g., Sjoers, 1950; Vitt and Slack, 1975; Andrus, 1986). Plant (particularly bryophyte) species, in turn, play a role in regulating the acidification of peatlands (Glime $e t$ al., 1982; Gorham et al., 1984, 1987). Acidification generally is thought to stem from uptake of cations on ion exchange sites on Sphagnum (e.g., Skene, 1915; Clymo, 1964). However, peatlands in continental North America often are forested; the importance of cation storage in woody biomass relative to on exchange sites in moss and peat is not known (cf. Reader and Stewart, 1972; Nilsson et al., 1982; Grigal, 1991). Peat and peatland vegetation often have low (possibly growth-limiting) concentrations of K (e.g., Malmer, 1962; Small, 1972; Buttleman and Grigal, 1985), but factors controlling the retention of $\mathrm{K}$ are poorly understood (cf. Hemond, 1980; Damman, 1986). Seasonal changes in K uptake and release of $\mathrm{K}$ and $\mathrm{Mg}$ have been shown (Boatman et al., 1975; Verry and Timmons, 1982; Damman, 1986), but the mechanisms remain unknown. To date, no mass balance studies for cations have been combined with measurements of pools and transfers within the peatlands, and hence little can be said about specific processes.

This paper summarizes the trends over the past 20 years in inputs, export and retention of major cations $(\mathrm{Ca}, \mathrm{Mg}, \mathrm{Na}, \mathrm{K})$ in a small peatland in northern Minnesota. Comparisons of cation pools in peat and vegetation demonstrate the reservoirs and processes responsible for net retention of each cation. Seasonal variations in ion ratios and in fluxes reveal the short-term processes controlling cation uptake; these processes are not necessarily those responsible for long-term, net retention.

\section{Methods}

\subsection{SITE DESCRIPTION}

The S-2 catchment is located in the Marcell Experimental Forest $\left(47^{\circ} 32^{\prime} \mathrm{N}\right.$, $93^{\circ} 28^{\prime} \mathrm{W}$ ) in north-central Minnesota. This region is characterized by a continental climate with wide temperature extremes and an annual average temperature of $3.1{ }^{\circ} \mathrm{C}$. Snow covers the ground from late November through mid-April, and accounts for $25 \%$ of annual precipitation $(76 \mathrm{~cm})$.

The S-2 catchment contains 6.5 ha of mineral-soil uplands surrounding 3.2 ha of wetland (see Verry, 1975; Verry and Timmons, 1982). A hummock-hollow microtopography exists in the peatland with hummocks rising up to $55 \mathrm{~cm}$ above the hollows (Verry, 1984). The wetland contains, on average, 4-m of peat overlaying limnic sediments that have sealed the basin and allowed development of a water table perched above the regional water table. This perched water table lies, on average, $10 \mathrm{~cm}$ below the surface of hollows; seasonally the water table fluctuates 
about $15 \mathrm{~cm}$ in average years (Verry et al., 1988). A gauged stream accounts for most water leaving the wetland; a small amount seeps out through the peat at the periphery of the wetland (Verry and Timmons, 1982). The wetland receives $30 \%$ of water inputs from the surrounding uplands, but most of this mineral-rich water is funneled to the outlet through a lagg zone about the bog periphery.

Within the past 200 years the wetland has shifted from a fen (circumneutral

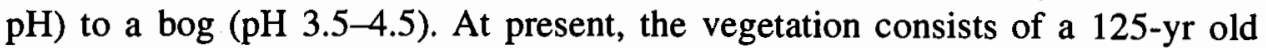
stand of black spruce (Picea mariana), an understory of Ericaceous shrubs (Ledum groenlandicum, Chamaedaphne calyculata, Gaultheria hispidula), and a carpet of bryophytes (Sphagnum magellanicum on hummocks, Sphagnum angustifolium in hollows; see Grigal, 1985; Grigal et al., 1985). The surrounding uplands are forested with a 64-yr old stand of aspen and birch (Populus tremuloides, Betula papyrifera).

\subsection{SAMPLING AND MEASUREMENT}

The S-2 catchment has been monitored intensively for the past 30 years. A vnotched weir was installed in 1960, and stream outflow, water table elevation, and precipitation volumes have been measured continuously since that time (Verry, 1975; Verry and Timmons, 1982; Verry, 1984; Verry et al., 1988). Streamwater chemistry has been monitored since 1968 ; bi-weekly sampling was augmented by additional samples during periods of high flow. Collectors for chemistry of bulk precipitation, throughfall and stemflow were installed for the periods 1971-73 and 1981-1983 (Verry and Timmons, 1977; Verry and Urban, 1992). An NADP (National Atmospheric Deposition Program) site was established in 1978 at a distance of $1 \mathrm{~km}$ from the S-2 catchment; wet deposition has been collected weekly from 1978 to the present (Verry, 1983). An identical wet-deposition collector was operated by the University of Minnesota at the same location from 1981 through 1985 (Metzer, 1986; Urban, 1987). Dry deposition was collected in plastic buckets (automatically covered during rain events) from 1978 through 1986 by NADP. Because of its relevance, bulk deposition in 1984 at a site $30 \mathrm{~km}$ southwest of the catchment also is presented.

Inputs to the wetland from the upland occur both via surface runoff (over and through the organic horizon) and interflow (through the A horizon above a less permeable B horizon). Experimental plots ( 2 each for surface runoff and interflow) to sample both components were installed in 1971, and inputs were monitored from 1971-73 and from 1981 to the present (Timmons et al., 1977; Urban et al., 1987, 1989c; Urban and Eisenreich, 1988). Volumes of interflow are estimated by hydrograph separation (Timmons et al., 1977; Verry and Timmons, 1982).

In addition to inputs and outputs, internal pools of cations in vegetation, pore waters, and peat were measured (Grigal, 1985; Grigal et al., 1985). In this paper, the vegetation is divided into four categories: trees, shrubs, herbs and mosses. There often is no clear distinction between living and dead moss, and hence the depth 
chosen to define the standing crop of moss is somewhat arbitrary. In this study we used a depth of $6 \mathrm{~cm}$; this corresponds to $1.5 \mathrm{y}$ of growth on hummocks and about 1 year's growth in hollows (Grigal, 1985). The category of trees includes seedlings, and living and dead standing trees. For trees and shrubs, size classes were inventoried in 6 to 30 plots, and on a subset of plots the plants were harvested for biomass and element content determinations. Biomass and element content were measured for foliage, live and dead branches, bark, bole, small and large roots. Roots of trees were collected in transects away from three trees, and root: shoot ratios were measured on 15 excavated shrubs. For graminaceous herbs both above and below ground biomass were inventoried; for non-graminaceous herbs (primarily Smilacina trifolia) only the above ground biomass was measured. Major cations were measured in a total of $1450-\mathrm{cm}$ peat cores; each core was sectioned into $2.5-\mathrm{cm}$ depth intervals. Extrapolation from $50-\mathrm{cm}$ to the average peat depth of 4-m was based on two long cores that extended to the basal peat.

Measurement of biomass and element concentrations in vegetation compartments was linked with measurements of growth and accumulation rates (Grigal, 1985; Grigal et al., 1985) to allow estimation of internal transfers (e.g., Urban et al., 1989c, 1990; Grigal, 1991). Litterfall was monitored for three years with 15 litter traps (Grigal et al., 1985). The understory of herbs and shrubs was assumed to be in steady-state, and productivity was calculated as the annual production of above-ground biomass plus the root turnover (one third of roots) for herbs, and for shrubs by regression of biomass and age data. Shrub foliage was assumed to have a half-life of one year. Growth and mortality of the tree stand was modeled with the computer program GROW (Grigal et al., 1985); model parameters were adjusted to fit the measured biomass distribution and mortality. Element uptake and accumulation were calculated as the concentration in individual plant parts (foliage, bark, bole, branches, roots) times the change in biomass in the respective compartments as calculated by the computer model. Accumulation is thus the difference between total uptake and litterfall. For the trees, mortality is not substracted from the accumulation because the pool of standing dead trees is aggrading; the rate of transfer from the pool of dead standing trees to the peat amounts to only $4 \%$ per year of the dead tree pool (Grigal et al., 1985). The category trees thus includes all standing trees, both live and dead. Growth of mosses was calculated individually for hummock and hollow species as the product of measured annual height increment and measured mass per unit height increment; the bog-wide growth rate $\left(376 \mathrm{~g} \mathrm{~m}^{-2}\right.$ $\mathrm{yr}^{-1}$ ) was calculated by weighting the hummock and hollow rates according to the areal coverage of each moss type (Grigal, 1985). The living biomass of bryophytes is not aggrading, and hence the accumulation rate in this pool is zero.

Analysis of all water samples for $\mathrm{Ca}, \mathrm{Mg}, \mathrm{Na}$ and $\mathrm{K}$ was by flame atomic absorption spectrophotometry. To obviate matrix effects, La was added to samples for $\mathrm{Ca}$ and $\mathrm{Mg}$ determinations and $\mathrm{Cs}$ was added to samples prior to measurement of $\mathrm{Na}$ and $\mathrm{K}$. Plant and peat samples were oven dried, dry-ashed $\left(550^{\circ} \mathrm{C}\right.$ for $3 \mathrm{~h}$ ), and the residue dissolved in aqua regia prior to cation analysis by plasma 
emission spectroscopy. Additional details on sample collection and measurement may be found in the references cited above. Cation mass balances for the S-2 catchment were published previously for the period 1971-73 (Verry and Timmons, 1982); the present paper adds the additional period 1981-1984 for complete mass balances, longer timespans for component fluxes, and the measured internal pools and fluxes. All fluxes and mass balances in this paper are calculated only for the peatland portion of the catchment.

\section{Results and Discussion}

\subsection{HYDROLOGICAL RECORD}

During the period 1960-1992 the S-2 catchment has received remarkably uniform annual precipitation (Figure 1). Single-year droughts (precipitation less than $80 \%$ of 30-yr mean) occur in about a 10-yr cycle $(1967,1976,1990)$. Similarly, wet years with precipitation greater than $20 \%$ above the mean $(1968,1977,1985$, 1988) occur about once per decade. Streamflow from the S-2 peatland is closely correlated with precipitation; on average, streamflow equals $66 \%$ of precipitation. Timing of precipitation can have a dramatic effect on the magnitude of outflow, however. A large storm (nearly $20 \mathrm{~cm}$ ) in early July, 1979, occurred before the bog water table had receded; upland soils were quickly saturated, and, without storage capacity in the peatland, this large input was flushed quickly through the wetland with the result that annual outflow was larger than precipitation to the peatland in this year. Low snow packs in 1980, 1983, and 1991 caused the outflow to be less than $50 \%$ of the mean although annual precipitation in these years was $85 \%$ of the annual mean. These annual hydrological variations help to clarify the roles of water flowpaths and flow rates in controlling element retention.

The seasonality of inputs and outputs of water induced by freezing (hence cessation) of the outflow in winter followed by snowmelt (Figure 2) is accentuated by inputs from the uplands. Surface runoff is confined largely to the period of snowmelt; interflow also is maximal during snowmelt, but increases again in fall. Even if element inputs from the upland were distributed uniformly within the peatland, it might be expected that retention of these inputs would be low because of the lower water retention efficiencies in spring and fall.

\subsection{CATION DEPOSITION}

Measurement of dry deposition remains a major problem in constructing ecosystem mass balances. Four techniques are available for estimating dry deposition. Particle size-dependent deposition velocities can be combined with measurements of atmospheric concentrations. This technique is most appropriate for elements associated with smaller particles; large soil particles undergo rapid, event-associated changes in concentrations. Attempts have been made to measure dry deposition to various 


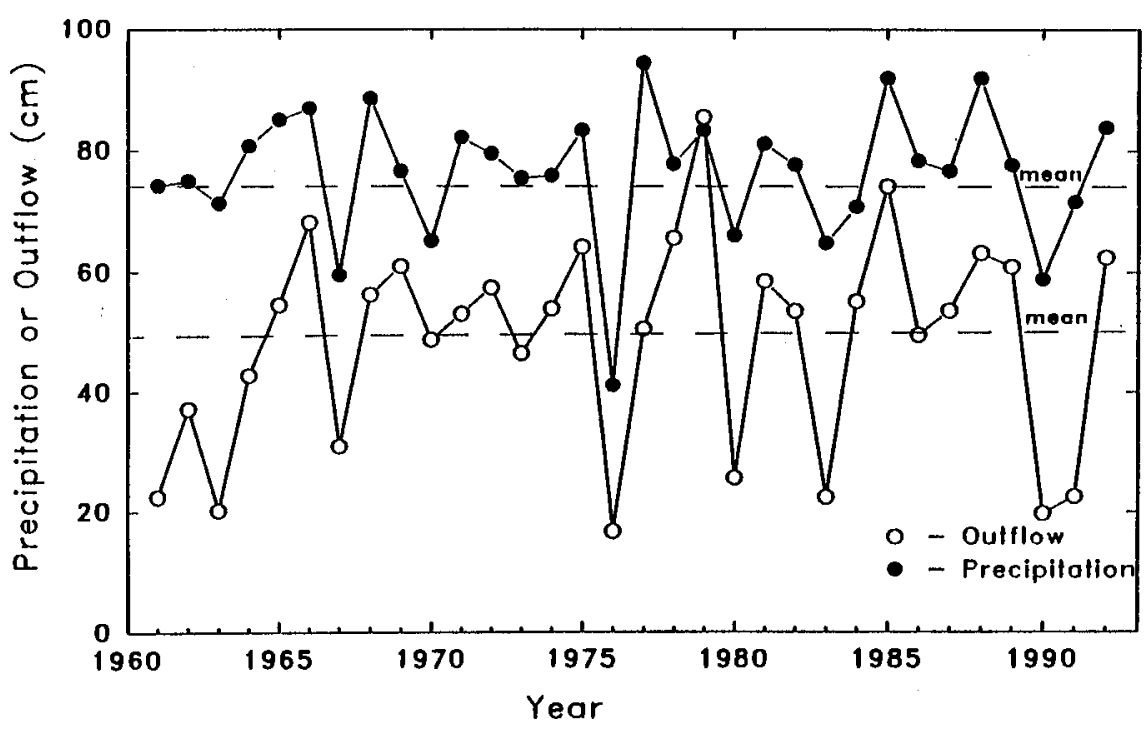

Fig. 1. Long-term record of precipitation and streamflow at the Marcell S-2 catchment. Outflow is expressed per unit area of wetland. Dashed lines represent means for the 32 years of record.

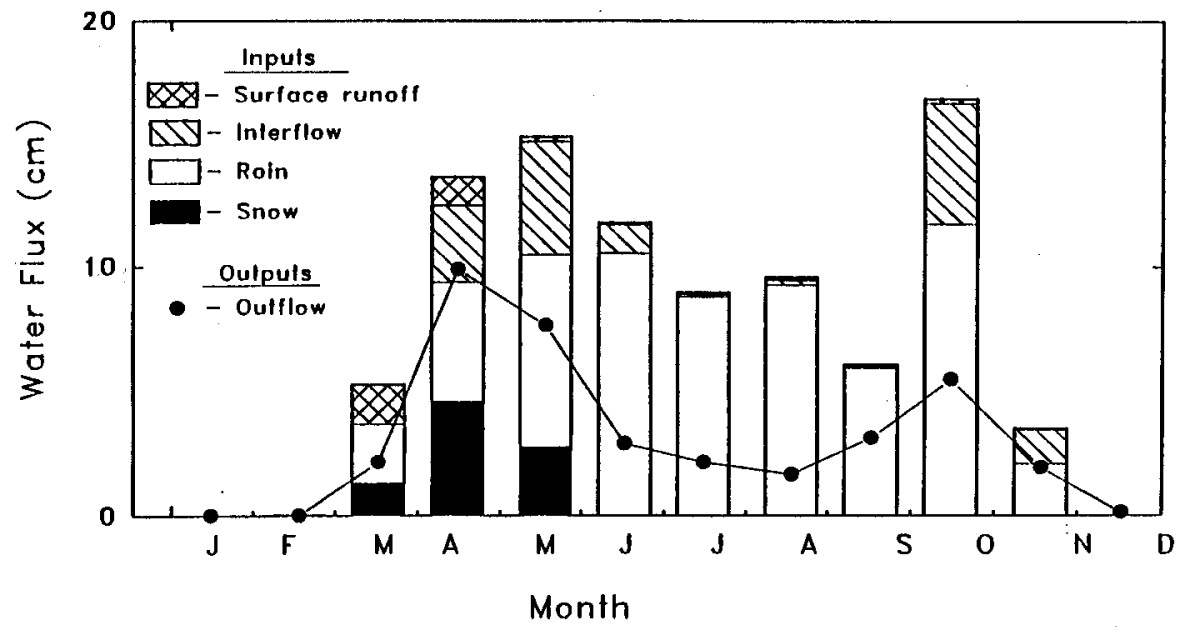

Fig. 2. Monthly water balance for the Marcell S-2 peatland. Values represent the mean of monthly values from 1981-1984. The outflow is frozen in winter, and snow inputs are shown only as inputs of snowmelt in spring.

surrogate surfaces (e.g., Cawse, 1974; Lindberg and Lovett, 1983); few surrogates mimic the surface roughness and available surface area of plant canopies, however. Both bulk deposition collectors and dry buckets probably underestimate dry 
deposition to plants. For elements that are not leached from within plant leaves and bark, measurement of throughfall can be a reliable technique for measuring total (wet plus dry) deposition (Mayer and Ulrich, 1982; Lindberg et al., 1986). Finally, if all other inputs and reaction terms for an ecosystem are known, export from or net change in storage in ecosystems can be used as an estimate of dry deposition (Driscoll et al., 1989). All of these techniques were applied in this study.

Total suspended particulate matter has been monitored by the Minnesota Pollution Control Agency (MPCA) at several stations within $50 \mathrm{~km}$ of the Marcell forest since 1976; no trend in aerosol concentration was observed in the period 1976-1982 (MPCA, unpub. data). Aerosol composition was measured 14-35 times at each of 15 sites in northeastern Minnesota over the course of a 10-month period; concentrations of $\mathrm{Ca}\left(148 \pm 298 \mathrm{ng} \mathrm{m}^{-3}\right.$; geometric mean \pm S.D. for all samples at all sites) and K (106 \pm 162$)$ were similar at all sites (Eisenreich et al., 1978). Size-fractionation with a multi-stage impactor showed that both $\mathrm{Ca}$ and $\mathrm{K}$ occurred primarily on large particles; the mass median diameter for $\mathrm{Ca}$ was 6.5 $\mu \mathrm{M}$. Deposition velocities for particles of this size to filter paper were measured to be in the range of $2.0-2.6 \mathrm{~cm} \mathrm{~s}^{-1}$ by Cawse (1974), although other investigators have reported lower deposition velocities for $\mathrm{Ca}$ to flat collection surfaces (1.11.9; Davidson and Elias, 1982; Lovett and Lindberg, 1983). Lovett and Lindberg (1984) calculated deposition velocities of $2.0-2.6 \mathrm{~cm} \mathrm{~s}^{-1}$ for Ca to a forest canopy; they did not, however, measure the mass-median diameter of the $\mathrm{Ca}$-containing aerosol. Using this range of deposition velocities with the measured aerosol $\mathrm{Ca}$ and $\mathrm{K}$ concentrations yields estimated dry deposition fluxes of $2.3-3.0 \mathrm{mmol} \mathrm{m}^{-2}$ $\mathrm{yr}^{-1}$ and $1.7-2.2 \mathrm{mmol} \mathrm{m}^{-2} \mathrm{yr}^{-1}$ for $\mathrm{Ca}$ and $\mathrm{K}$, respectively.

These estimates of dry deposition are in good agreement with measurements in dry bucket collectors $\left(1.7 \pm 0.6 \mathrm{mmol} \mathrm{Ca} \mathrm{m}^{-2} \mathrm{yr}^{-1}\right.$ and $1.0 \pm 0.5 \mathrm{mmol} \mathrm{K}$ $\mathrm{m}^{-2} \mathrm{yr}^{-1}$; mean \pm S.D. for 1979-1983; NADP, unpub. data). This period is too short to assess trends, but deposition in 1982 and 1983 was lower for all cations than in the previous three years. The dry bucket deposition represents $125 \%$ of the wet deposition of $\mathrm{K}, 44 \%$ for $\mathrm{Mg}, 38 \%$ for $\mathrm{Ca}$, and $10 \%$ for $\mathrm{Na}$. These dry:wet bucket ratios at Marcell are similar to those observed throughout the upper midwest $(\mathrm{K}-1.64 ; \mathrm{Mg}-0.65 ; \mathrm{Ca}-0.54 ; \mathrm{Na}-0.22 ;$ Baker, 1991).

For all four cations there was a large discrepancy between the estimates of dry deposition discussed above and those calculated from throughfall (Table I). Throughfall should equal the sum of wet plus dry deposition plus any leaching of cations from the canopy (canopy reaction). However, throughfall was 2-2.6 times greater than wet plus dry bucket fluxes of $\mathrm{Ca}, \mathrm{Mg}$ and $\mathrm{Na}$. A large throughfall flux of $\mathrm{K}$ is not unexpected; large canopy reaction terms have been noted previously for K (e.g., Cronan and Reiners, 1983; Lovett and Lindberg, 1984). It is not clear if the large difference between throughfall and wet-only deposition for the other three cations resulted from dry deposition or canopy reaction. If dry deposition accounted for the entire difference between fluxes in throughfall and wet-only precipitation collectors, the tree canopy would have to be more efficient than dry buckets at 
collecting dry deposition by factors of $5.2(\mathrm{Ca})$ to $12.8(\mathrm{Na})$. Lindberg and Lovett (1983) observed different capture efficiencies for large particles by deciduous leaf surfaces and adjacent inert, artifical surfaces; the mean (1.7-fold) and range (0.9to 3.2-fold) of differences in capture efficiencies reported by these authors are much smaller than those inferred from the present study. The discrepancy suggests that either canopy reactions contributed to the throughfall fluxes of all four cations (especially $\mathrm{Na}$ and $\mathrm{K}$ ), or the coniferous forest was much more efficient than the dry bucket at collecting dry deposition. It is well known that all four cations are leached from foliage of decidous trees by rain (e.g., Verry and Timmons, 1977; Lovett and Lindberg, 1984); data for coniferous forests are not as abundant, but substantial leaching of $\mathrm{Ca}, \mathrm{Mg}$ and $\mathrm{K}$ has been reported (Henderson et al., 1977; Cronan and Reiners, 1983). It also has been shown that coniferous forests are more efficient in collecting dry deposition than are deciduous forests (Rohbock, 1982; Gravenhorst et al., 1983). It seems likely that the discrepancy between throughfall and wet plus dry collectors results from both canopy reactions and dry deposition.

Bulk deposition collectors also recorded much larger fluxes than wet plus dry collectors, and indicated that deposition of all cations increased from 1971-1973 to 1981-1983 (Figure 3). For all cations except $\mathrm{K}$ there also was an increase in bulk deposition from 1981 to 1984 . This increase was not shown by the wet and dry bucket collectors, but throughfall collectors did show such an increase for $\mathrm{Ca}$ and $\mathrm{Mg}$ although not for $\mathrm{Na}$. A bulk deposition collector operated in 1984 at a site (Prairie River Gorge) $30 \mathrm{~km}$ southwest of the S-2 catchment exhibited even higher deposition of $\mathrm{Ca}, \mathrm{Mg}$ and $\mathrm{Na}$ than was observed in 1983 at the Marcell site. This might indicate that the trend of increasing deposition continued, or that this collector was located closer to the source of the cation emissions. An increase in particle deposition over the period of study may be quite reasonable given the large increase in production capacity of a local, coal-fired power plant. This plant, located $50 \mathrm{~km}$ southwest of the Marcell site and only $20 \mathrm{~km}$ from the Prairie River Gorge, increased its power production capacity from 200 megawatts in 1972 to 500 megawatts in 1973 to 1000 megawatts in 1980. Even though the prevailing winds are from the northwest at Marcell, both the bulk deposition and throughfall measurements demonstrate that an increase in deposition of $\mathrm{Ca}, \mathrm{Mg}$ and $\mathrm{Na}$ has occurred concurrently with an increase in local power production. The higher deposition in 1984 at the Prairie River Gorge site in comparison with 1983 deposition at Marcell is consistent with the hypothesis that the local power plant is the cause of the increased cation deposition. Additional evidence is needed to prove this causality.

An assessment of trends in cation deposition should be based on similar measurement techniques, but the techniques used at Marcell yield conflicting results. No trends are evident in wet deposition of $\mathrm{Ca}, \mathrm{Mg}$ or $\mathrm{K}$ over the period 19791992 (Figure 3). The apparent decline in wet deposition of Na from 1979-1982 is spurious; contamination from sealing rings caused over-estimates of deposition in 1979-1981. The sum of wet and dry bucket deposition appeared to decrease 
TABLE I

Estimates of atmospheric deposition (mmol m $\mathrm{m}^{-2} \mathrm{yr}^{-1}$, S.D. in parenthesis) of major cations

\begin{tabular}{lllllcc}
\hline Year & $\begin{array}{l}\text { Dry } \\
\text { deposition }^{a}\end{array}$ & $\begin{array}{l}\text { Dry } \\
\text { bucket }^{b}\end{array}$ & $\begin{array}{l}\text { Wet } \\
\text { bucket }^{c}\end{array}$ & W $+\mathrm{D}^{d}$ & Bulk $^{e}$ & Throughfall $^{f}$ \\
\hline $\mathrm{Ca}$ & 2.3 & 1.7 & 4.6 & 6.2 & 11.0 & 13.4 \\
& & $(0.6)$ & $(0.7)$ & $(1.0)$ & $(3.1)$ & $(2.8)$ \\
& & $\mathrm{n}=5^{g}$ & $\mathrm{n}=7$ & $\mathrm{n}=5$ & $\mathrm{n}=7$ & $\mathrm{n}=6$ \\
$\mathrm{Mg}$ & $\mathrm{nm}$ & 0.61 & 1.4 & 2.0 & 3.4 & 5.2 \\
& & $(0.25)$ & $(0.3)$ & $(0.4)$ & $(0.7)$ & $(0.8)$ \\
& & $\mathrm{n}=5$ & $\mathrm{n}=7$ & $\mathrm{n}=5$ & $\mathrm{n}=7$ & $\mathrm{n}=6$ \\
$\mathrm{~K}$ & 1.7 & 1.0 & 0.8 & 1.8 & 4.5 & 10.7 \\
& & $(0.5)$ & $(0.1)$ & $(0.5)$ & $(1.6)$ & $(1.6)$ \\
& & $\mathrm{n}=5^{g}$ & $\mathrm{n}=7$ & $\mathrm{n}=5$ & $\mathrm{n}=7$ & $\mathrm{n}=6$ \\
$\mathrm{Na}$ & $\mathrm{nm}$ & 0.4 & 4.1 & 4.5 & 8.8 & 9.2 \\
& & $(0.2)$ & $(3.2)$ & $(3.8)$ & $(3.8)$ & $(5.9)$ \\
& & $\mathrm{n}=5$ & $\mathrm{n}=7$ & $\mathrm{n}=5$ & $\mathrm{n}=7$ & $\mathrm{n}=6$ \\
\hline
\end{tabular}

a Estimate based on mass-median diameter of $\mathrm{Ca}$ and $\mathrm{K}$ in aerosols (data from Eisenreich et al., 1978) and appropriate deposition velocities (see text).

${ }^{6}$ Mean of dry bucket collections by NADP from 1979 through 1983.

c Mean of wet buck collections by NADP from 1978-1985.

d Sum of wet and dry bucket collections.

$e$ Based on bulk deposition collectors of the U.S. Forest Service operated in 19711973 and 1981-1984.

$f$ Throughfall collectors operated by U.S. Forest Service in 1971-1973 and 19811983; see Verry and Timmons (1977) for details.

$g$ refers to the number of years of measurement that are averaged.

for $\mathrm{Ca}, \mathrm{Mg}$ and $\mathrm{K}$, but the period of record is too short to conclude that a trend exists. If the bulk deposition values are correct, however, a substantial increase in deposition of $\mathrm{Ca}, \mathrm{Mg}, \mathrm{K}$ and especially $\mathrm{Na}$ has occurred between 1971 and 1985. The measurements of throughfall also indicate that an increase in $\mathrm{Na}$ deposition has occurred; annual variations obscure any change in $\mathrm{Ca}$ and $\mathrm{Mg}$ in throughfall. The large canopy reaction for $\mathrm{K}$ may render throughfall insensitive to changes in atmospheric deposition. As discussed below, streamflow measurements also show increased $\mathrm{Na}$ fluxes over this time period. It is reasonable to expect that throughfall would be a more sensitive indicator of changes in dry deposition than would: dry bucket collectors. It is not at all apparent, however, why the bulk deposition collector would record the inferred increase in short-range fallout of fly ash while wet-only and dry-only collectors showed no such increase. Clearly, addtional measurements of bulk deposition or throughfall will be required to determine whether increased cation deposition at Marcell has persisted. 


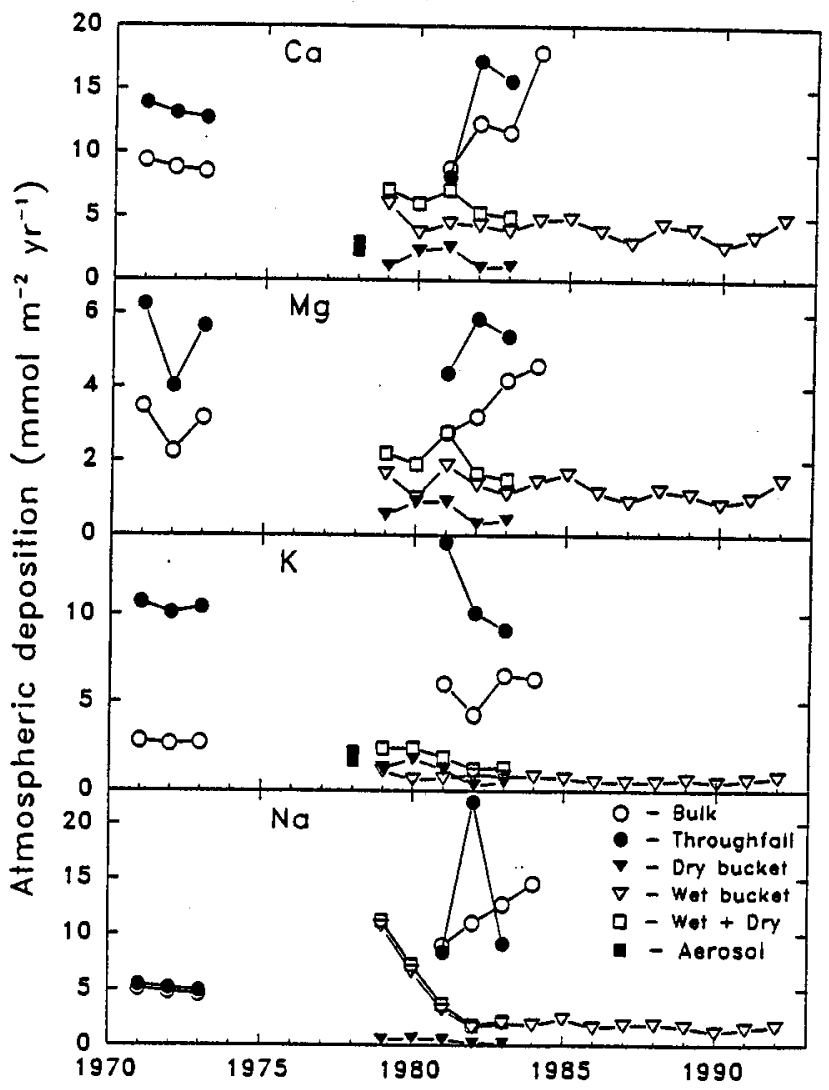

Fig. 3. Trends in atmospheric deposition of cations to the Marcell S-2 catchment. Filled squares for $\mathrm{Ca}$ and $\mathrm{K}$ represent estimated dry deposition based on measured aerosol concentrations and deposition velocities (see text). The reason for the large disparity between bulk deposition and (wet + dry) deposition in 1981-1984 is not known. If the bulk deposition measurements were accurate, a significant increase in atmospheric deposition of all cations occurred between 1971 and 1983. The decrease in wet deposition of $\mathrm{Na}$ between 1979 and 1982 is spurious; contamination of collectors occurred in 1979-1981.

\subsection{UPLAND RUNOFF}

As noted above, upland runoff occurred primarily during snowmelt, and hence the magnitude of inputs from the upland depended largely on the size of the snowpack. In the four years 1981-1984, upland runoff was largest in the two years with the largest snow packs $(1981,1984)$. Factors such as duration of snowmelt and soil moisture content also can play a role in determining how much snowmelt runs off into the wetland and how much seeps down to the groundwater table. Rapid snowmelt in 1981 led to rapid saturation of the upland soils, and most of the first flush of cations from snowmelt reached the wetland. Among the seven years for 
which results are presented here, the magnitude of annual upland runoff of water varied 3-fold.

For all cations, upland runoff was the dominant input to the wetland for all years. Atmospheric deposition of $\mathrm{K}$ and $\mathrm{Na}$ nearly equaled the reduced upland export in 1983. All cations except $K$ showed similar trends in annual inputs from surface runoff (Figure 4b-e). Inputs decreased slightly from 1971 to 1973, peaked in 1981, and decreased significantly in 1982-1984. To a large extent these patterns followed the pattern of water inputs (Figure 4a). The peak in 1981 may have been due to the early snowmelt, as mentioned above. Potassium differed from the other three cations in that $85 \%$ of upland export of $\mathrm{K}$ was via surface runoff; only about $55 \%$ of $\mathrm{Ca}$ and $\mathrm{Mg}$ export and 30\% of $\mathrm{Na}$ export occurred via surface runoff. Export of $\mathrm{K}$ was regulated by an interplay between soil temperature and water availability; export was maximal in years (1973) with deep soil frost followed by adequate runoff to transport the mobilized K. Deep soil frost in the uplands also occurred in 1983 , but the small snowpack provided inadequate runoff to move the $K$ downslope to the peatland. High upland runoff without significant frost penetration in upland soils $(1971,1981)$ does not result in large export of $K$ from the uplands.

\subsection{STREAMFLOW AND RETENTION}

Streamflow was relatively stable over the years depicted in Figure 1; the minima in 1983 and 1991 were primarily due to low snow packs rather than reduced annual precipitation (Figure 1). Low water export in 1983 and 1991 resulted in lowered export of each of the cations (Figure 4). Export of $\mathrm{Ca}$ and $\mathrm{Mg}$ (Figure 4b, c) largely parallelled the trend in water export while both $\mathrm{Na}$ and $\mathrm{K}$ experienced changes in mean concentrations in the outflow over this time period. Export of $\mathrm{Na}$ increased over the period 1969-1992, and export of K remained below pre-1973 levels until 1992. The increase in export of $\mathrm{Na}$ from the period 1971-1973 to the period 19811984 ( $3 \mathrm{mmol} \mathrm{m}^{-2} \mathrm{yr}^{-1}$; the value for the drought year is not included) is smaller than the increases in either bulk deposition $\left(7 \mathrm{mmol} \mathrm{m}^{-2} \mathrm{yr}^{-1}\right)$ or throughfall $\left(8 \mathrm{mmol} \mathrm{m} \mathrm{m}^{-2} \mathrm{yr}^{-1}\right.$ ); the peatland may buffer, at least temporarily, the outflow from responding to changes in inputs. The change in $\mathrm{K}$ export was in the opposite direction as the change in bulk deposition, perhaps as a result of decreased upland inputs in the period 1981-1983.

Comparison of total inputs and outputs indicates that the peat deposit acts as a net sink for each cation, although the retention efficiencies vary greatly from year to year (Figure $4 \mathrm{~b}-\mathrm{e}$ ). Values of retention efficiencies depend on which values of atmospheric deposition are used (Table II). Ca is retained most efficiently (35-62\%), and $\mathrm{K}$ exhibits the largest annual variability (-15-63\%). When bulk deposition measurements are used for the atmospheric input, $\mathrm{Na}$ appears to be retained more efficiently than $\mathrm{Mg}$, but when wet and dry bucket measurements are used then the retention efficiencies for both ions are similar. Hemond (1980) previously reported retention of $45 \%$ of $\mathrm{Mg}$ inputs and retention of $-25 \%$ to $+25 \%$ 


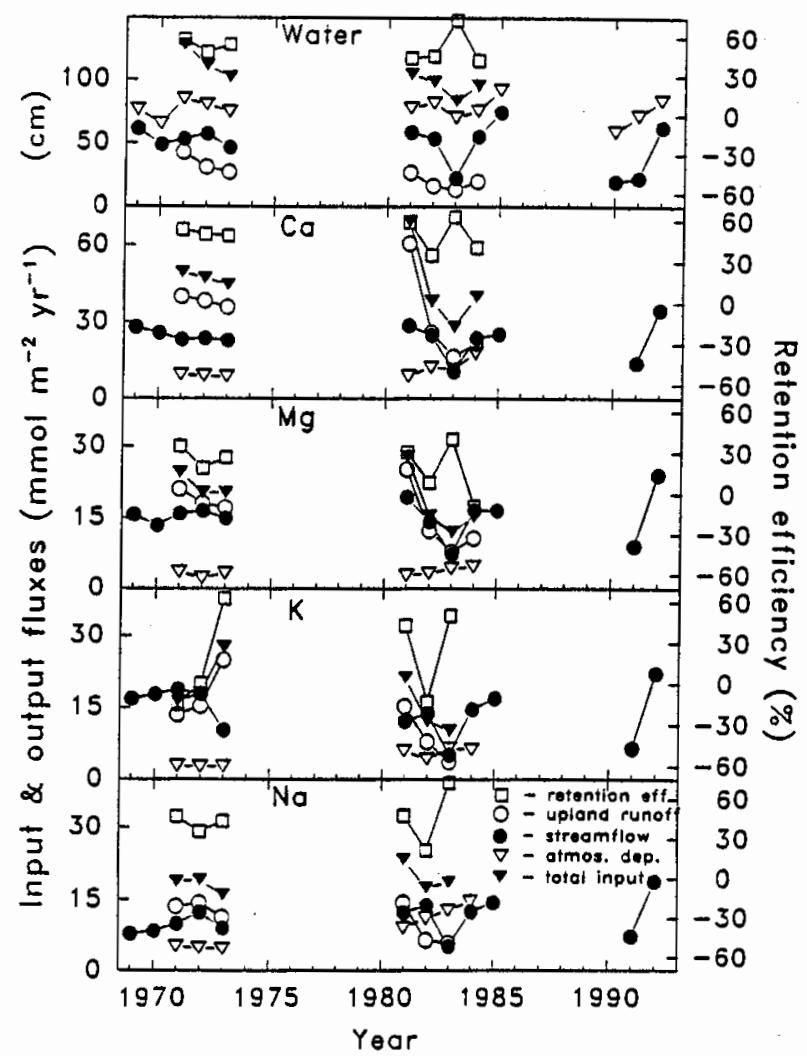

Fig. 4. Component fluxes for cation mass balances at the Marcell S-2 peatland. No measurements were made in the interval 1974-1978. No measurements of dry deposition were made for the period 1986-1992, and hence data for the other fluxes are not shown. Streamflow for 1991-1992 is shown to evaluate long-term trends in this flux. Bulk deposition measurements were used for atmospheric deposition fluxes.

of $\mathrm{K}$ inputs for a floating mat bog; his values are similar to those found in this study. Rather than drought causing net oxidation of peat and increased release of cations (cf. LaZerte, 1993), the drought year at Marcell resulted in a high net retention of all cations. Decreased inputs from the uplands in 1982-84 have, apart from the 'drought' year, caused a decreased retention efficiency for each cation. In other words, the export from the wetland has remained relatively stable while the inputs have decreased. The peat would appear to act as a buffer preventing rapid responses in output to changing inputs.

Additional insight into this buffering of streamflow by the peatland may be gained by viewing the mass balance on a monthly rather than annual timescale (Figure 5). The dominance of upland runoff as a cation source is shown in the bar for the average monthly flux. However, most of the input from the upland occurs in April, May and October. In these months the retention efficiency of the wetland 


\section{TABLE II}

Retention efficiencies ([1-output/input] $\times 100)$ for cations in the $S-2$ peatland

\begin{tabular}{lllll}
\hline Year & $\mathrm{Ca}$ & $\mathrm{Mg}$ & $\mathrm{Na}$ & $\mathrm{K}$ \\
\hline 1971 & 53 & 35 & 47 & -15 \\
1972 & 50 & 19 & 35 & 0 \\
1973 & 49 & 27 & 43 & 63 \\
1981 & $58(59)^{\mathrm{a}}$ & $30(32)$ & $48(33)$ & $43(37)$ \\
1982 & $35(22)$ & $8(1)$ & $21(-36)$ & $-13(-30)$ \\
1983 & $62(72)$ & $40(57)$ & $72(52)$ & $50(65)$ \\
1984 & 40 & -9 & & \\
Mean & 50 & 22 & 44 & 21 \\
\hline
\end{tabular}

a Values in parentheses are calculated using the sum of wet plus dry bucket deposition rather than bulk deposition.

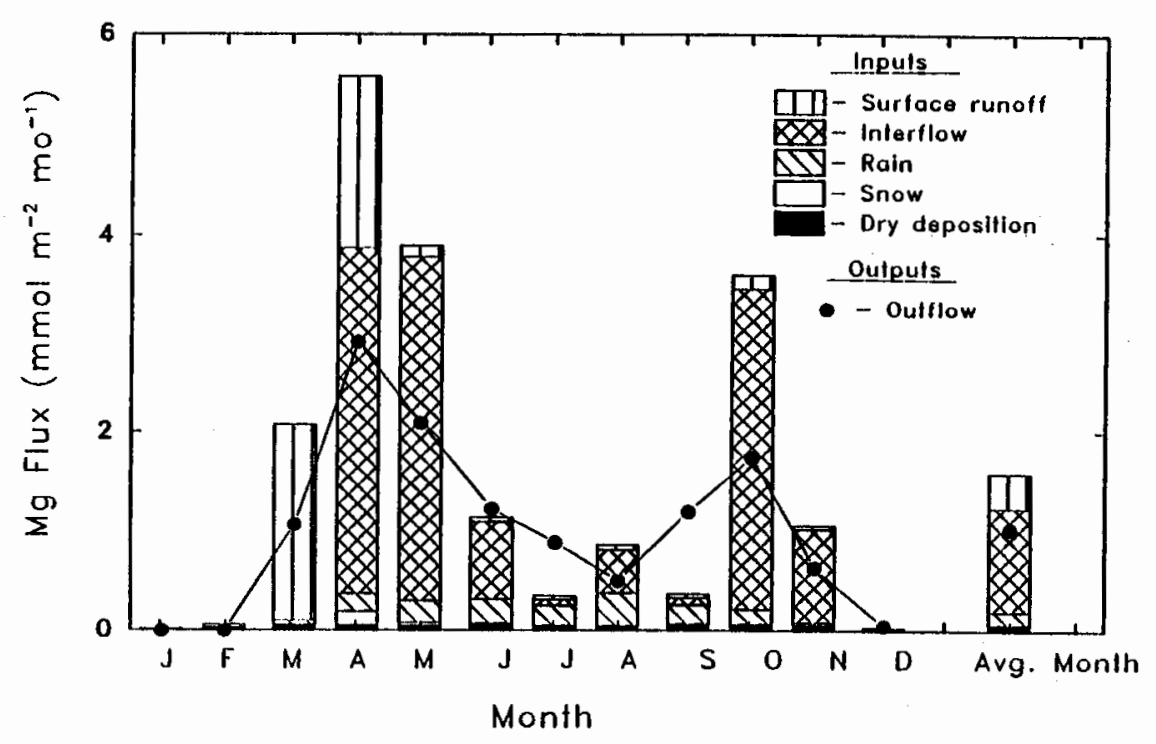

Fig. 5a.

for cations is highest $(55-70 \%)$, even though the water retention efficiency and water retention times are lowest (Figure 2). In summer months when atmospheric deposition accounts for the majority of the input, outputs actually exceed inputs.

There are three possible explanations for this seasonal variation in retention efficiency. One interpretation would be that atmospherically deposited inputs are not retained in the peatland. However, accumulation rates of the cations in peat 


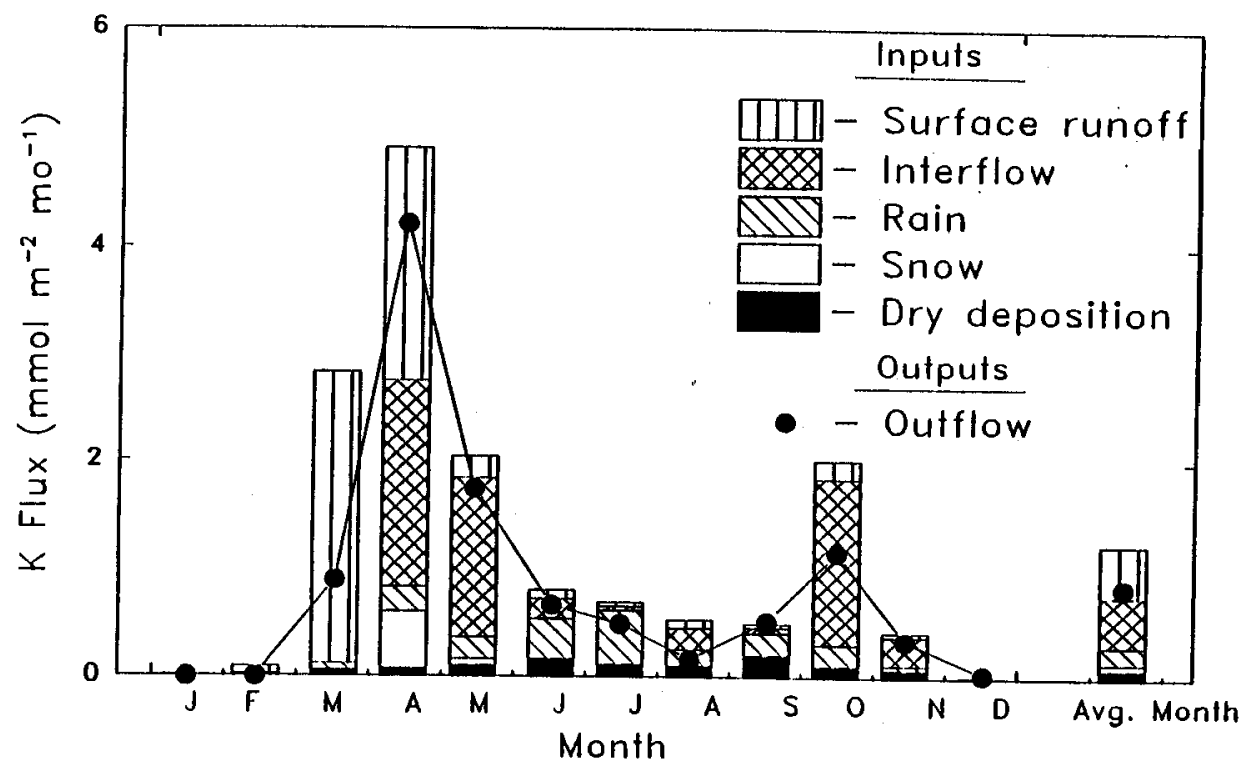

Fig. 5b.

Figs. 5(a)-(b). Monthly mass balance for $\mathrm{Mg}(\mathrm{A})$ and $\mathrm{K}$ (B) at the Marcell S-2 peatland. Values represent the averages for 1981-1984. The final column represents the annual mean divided by twelve. Monthly mass balances for $\mathrm{Ca}$ and $\mathrm{Na}$ (not shown) show similar seasonal variations. Upland runoff is the dominant source for all cations, although the proportion varies from $74 \%$ of total inputs for $\mathrm{Na}$ to $86 \%$ for $\mathrm{Ca}$ and $\mathrm{Mg}$. For $\mathrm{Ca}, \mathrm{Mg}$ and $\mathrm{Na}$ export exceeds inputs in July and September, but for $\mathrm{Na}$ and $\mathrm{Ca}$ there is a net retention in the peatland in June and August.

in the center of the bog closely approximate the rates of atmospheric deposition (Eisenreich et al., 1984). The explanation usually proffered is that retention efficiency is high when plants are actively growing and rapidly taking up nutrients; reduced growth and even senescence lead to lowered retention (Verry and Timmons, 1982; Damman, 1986). However, net export in summer months (June, July and September for $\mathrm{Mg}$; Figure 5a) requires that cations that were retained in spring are released during summer. A third hypothesis would be that cations are taken up on ion exchange sites in spring when concentrations in inflowing upland runoff are high, and subsequently released during summer months when concentrations in the input waters (rain) are lower. As mentioned above, this buffering occurs over longer timescales as well; decreasing inputs from the uplands in 1982-84 did not cause decreased export presumably because release of cations from exchange sites compensated for decreased inputs. Gies and Loetschert (1973) and Urban and Bayley (1986) have previously described such buffering occurring over shorter timescales (hours to days) as well. This third hypothesis is supported by the differing behaviors of the ions; among the four cations, retention efficiencies in summer months are highest for those cations for which uptake into living plant tissues is 
important. K (Figure $5 \mathrm{~b}$ ) which is taken up primarily into living tissue rather than onto ion exchange sites (e.g., Malmer, 1962; Damman, 1986; Andrus, 1986) does not exhibit a net export in summer months although retention efficiencies are lower than in spring and fall. Retention efficiencies are lowest in summer for $\mathrm{Mg}$ (Figure 5a) which, as discussed below, appears to undergo the least storage in biomass.

\subsection{MECHANISMS OF CATION RETENTION}

There are two mechanisms for medium-term (i.e., 1-50 yr) retention of cations in bogs: storage in aggrading plant biomass and storage in the aggrading pool of peat. The importance of an aggrading pool of vegetation will be greatest in forested sites because of the magnitude of Ca storage in woody biomass. Short-term (hours to months) retention may occur as cations are taken up by herbaceous plants or adsorbed on ion exchange sites on bryophytes. However, these pools usually are constant over longer time periods (cf. LaZerte, 1993), and hence these pathways for cation uptake do not result in long-term retention. Over time periods greater than 50 to $100 \mathrm{y}$, the plant biomass is unlikely to continue to aggrade, and storage in peat is the only long-term mechanism for cation retention.

The relative importance of cation storage in plant biomass and in peat as well as the accuracy of the mass balances may be assessed by quantifying the cation pools and their accumulation rates within the peatland. For the S-2 peatland there is remarkably good agreement between the estimates of storage within the ecosystem based on input/output mass balances and measured accumulation rates for $\mathrm{Ca}, \mathrm{Mg}$ and $\mathrm{Na}$ (Table III). The closeness of agreement may be fortuitous given the spatial heterogeneity of cation concentrations in the peat and the annual variability in input/output mass balances (Table II). As given, the mass balances for the two input measurements (bulk vs. wet and dry collectors) are not strictly comparable; the mean retention for seven years (1971-1973, 1981-1984) is given based on bulk deposition while the mean for only four years is given for the wet plus dry collectors. There is not a large difference for any of the cations except $\mathrm{Na}$; the retention estimate based on wet and dry collectors is closer to the measured rate of accumulation. However, if $\mathrm{Na}$ inputs are increasing, storage may not yet have reached a steady state, and the measured rates of storage may reflect previous conditions. The agreement among estimates of $\mathrm{Ca}$ and $\mathrm{Mg}$ retention in the peatland is taken as confirmation of the accuracy of the mass balances.

The cation mass balances demonstrate that the cation retention capacity of the peatland is limited; only $20-50 \%$ of cation inputs are retained, on average, and in some years a net export occurs (Table II). These observations seem to conflict with the perception that Sphagnum and peat represent a large ion exchange matrix with a large cation uptake capacity. Peat does indeed represent a large cation reservoir as shown by the magnitude of the cation pools in the peat (Table III); the 15-cm depth over which the water table fluctuates in an average year (Verry, 1984) contains 15 -years worth of $\mathrm{Ca}$ and $\mathrm{Mg}$ (total) inputs. This large pool of cations enables the 
seasonal and multi-year buffering of cation export discussed above. It should be noted that the living moss does not represent such a large pool for exchangeable cations; this reservoir equals only 1-year's inputs of $\mathrm{Ca}$ and $\mathrm{Mg}$ although it does contain an amount equal to 5- to 20-years of $\mathrm{K}$ inputs. The large reservoir of cations in peat should not, however, be equated with a large accumulation rate. Most of the annual production of organic matter in peatlands is decomposed and does not accumulate. Generally, about $85 \%$ of organic matter produced in bogs is decomposed annually; decomposition in fens is even more extensive. In the S-2 peatland, peat accumulation $\left(145 \mathrm{~g} \mathrm{~m}^{-2} \mathrm{yr}^{-1}\right)$ represents only $17 \%$ of the current rate of biomass production, but equals $38 \%$ of bryophyte production. Hence only a small fraction $(<40 \%)$ of the cations initially bound on exchange sites on Sphagnum will be permanently buried on such exchange sites. An even smaller fraction of the cations originally bound in vascular plant biomass will accumulate over timescales of decades to centuries (e.g., Clymo, 1987). For this reason, the accumulation rates are much less than the uptake rates (Table III).

What role does ion exchange play in the retention of cations within the S2 peatland? The seasonal and multi-year uptake and release that serve to buffer export have been mentioned above. However, ion exchange results in longer-term retention only of those cations bound on exchange sites on peat that accumulates. Accumulation within the peat accounts for only $14 \%(\mathrm{~K})$ to $76 \%(\mathrm{Na})$ of the annual cation retention within the $\mathrm{S}-2$ peatland (Table III). The retention via accumulation in peat of all cations combined amounts to less than $25 \mathrm{meq} \mathrm{m}^{-2} \mathrm{yr}^{-1}$ (ion exchange per se probably accounts for only about $70 \%$ of the total cations bound in peat; Gore and Allen, 1956; Puustjarvi, 1957; Urban, unpub.). This source of acidity is comparable to rates of acid deposition at this site (10-20 meq m $\mathrm{m}^{-2} \mathrm{yr}^{-1}$; Munger and Eisenreich, 1983; Verry, 1983; Baker et al., 1991), but much less than the rates of organic acid production in this site $\left(250 \mathrm{meq} \mathrm{m}^{-2} \mathrm{yr}^{-1}\right.$; Urban et al., 1989a). In this bog ion exchange is not a major source of acidity (cf. Clymo, 1964, 1967, 1987; Andrus, 1986). Any peatlands with lower inputs of base cations (e.g., raised bogs lacking upland runoff) will generate even less acidity (annually) through ion exchange. When subjected to high rates of acid deposition (e.g., $55 \mathrm{meq} \mathrm{m}^{-2} \mathrm{yr}^{-1}$ wet deposition of $\mathrm{H}^{+}$as in Dorset, Ontario) even fens with large cation inputs from surrounding mineral soils can experience net stripping of cations from the peat and hence an acidification of the peat (LaZerte, 1993). Under such circumstances, ion exchange neutralizes the acidity and thereby serves as a source of alkalinity to the inflowing water although the peat is acidified as a result (Kilham, 1982; Bayley $e t$ al., 1986, 1987; Urban and Bayley, 1986).

Accumulation within woody biomass is a major mechanism for retention of cations in the S-2 peatland, and probably for other forested peatlands as well. Even though the accretion of biomass by the tree stand in the S-2 site has slowed considerably from its maximal rates (biomass/accretion $=180 \mathrm{yr}$ vs. 125 -yr age of tree stand), it is retaining cations (in particular, $\mathrm{Ca}$ and $\mathrm{K}$ ) at rates comparable to the rates of cation storage in the peat. Part of this storage occurs via mortality 
TABLE III

Pools and uptake rates of cations by vegetation and peat

\begin{tabular}{|c|c|c|c|c|c|}
\hline Compartment & $\mathrm{Ca}$ & $\mathrm{Mg}$ & $\mathrm{Na}$ & $\mathbf{K}$ & Biomass \\
\hline Pool $^{a}$ & \multicolumn{4}{|c|}{$\left(\mathrm{mmol} \mathrm{m}^{-2}\right)$} & $\left(\mathrm{g} \mathrm{m}^{-2}\right)$ \\
\hline Moss & 46 & 23 & 7.2 & 107 & 500 \\
\hline Trees & 1134 & 216 & 10.8 & 418 & 13500 \\
\hline Shrubs & 20 & 8.5 & 0.8 & 17 & 250 \\
\hline Herbs & 2 & 3 & 0.03 & 20 & 110 \\
\hline Vegetation $^{b}$ & 1202 & 250 & 19 & 562 & 14360 \\
\hline Peat $^{c}$ & 20000 & 8400 & 6800 & 4800 & 400000 \\
\hline Uptake $^{a}$ & \multicolumn{4}{|c|}{$\longrightarrow\left(\mathrm{mmol} \mathrm{m}^{-2} \mathrm{yr}^{-1}\right)$} & $\left(\mathrm{g} \mathrm{m}^{-2} \mathrm{yr}^{-1}\right)$ \\
\hline Moss & 35 & 17 & 5.4 & 80 & 376 \\
\hline Trees & 56 & 10 & 1.3 & 12 & 294 \\
\hline Shrubs & 13 & 3 & 0.3 & 6 & 105 \\
\hline Herbs & 2 & 3 & 0.03 & 20 & 51 \\
\hline Vegetation $^{b}$ & 106 & 33 & 7 & 118 & 826 \\
\hline \multicolumn{6}{|l|}{ Peat $^{c}$} \\
\hline Accummulation $^{a}$ & \multicolumn{4}{|c|}{$\longrightarrow\left(\mathrm{mmol} \mathrm{m}^{-2} \mathrm{yr}^{-1}\right)$} & $\left(\mathrm{g} \mathrm{m}^{-2} \mathrm{yr}^{-1}\right)$ \\
\hline Moss & 0 & 0 & 0 & 0 & 0 \\
\hline Trees & 7 & 2 & 0.5 & 5 & 75 \\
\hline Shrubs & 6 & 2 & 0.2 & 5 & 72 \\
\hline Herbs & 0 & 0 & 0 & 0 & 0 \\
\hline Vegetation (live) & 13 & 4 & 0.7 & 10 & 147 \\
\hline Mortality $^{d}$ & 4 & 1 & 0.1 & 2 & 82 \\
\hline Peat & $\underline{7}$ & $\underline{3}$ & $\underline{2.5}$ & $\underline{2}$ & 145 \\
\hline Total & 24 & 8 & 3.3 & 14 & 374 \\
\hline \multicolumn{6}{|c|}{ Accumulation based on input - output budgets } \\
\hline using bulk deposition ${ }^{e}$ & $23(8)$ & $4(3)$ & $8(3)$ & $4.6(7)$ & \\
\hline using wet + dry bucket & $25^{f}$ & 6 & 3 & 4 & \\
\hline
\end{tabular}

a Data from Grigal (1985), Grigal et al. (1985).

- Sum of all vegetation pools, above- and below-ground.

c Estimated pool in four meters of peat based on mean concentrations in 14 peat cores.

d Mortality represents production of dead tissues (primarily wood) that remain in place.

- Mean for seven years with S.D. given in parenthesis.

$f$ Mean for three $(\mathrm{K}, \mathrm{Na})$ or four $(\mathrm{Ca}, \mathrm{Mg})$ years. 
and an accumulation of dead wood both above and below ground. Modeling of the growth dynamics of the tree stand indicated that it is close to reaching a steady state with respect to living biomass (Grigal et al., 1985) and hence, presumably, also with respect to cation accumulation. The absence of a trend toward decreasing retention efficiency for $\mathrm{Ca}$ over a $15 \mathrm{yr}$ interval in which growth of the tree stand in the $\mathrm{S}-2$ peatland has slowed suggests that a decrease in net cation uptake (i.e., accumulation) by the trees will lead to either accretion within the pool of standing dead trees (representing only temporary storage), greater uptake and accretion within the shrub community (cf. Reader and Stewart, 1972; Grigal, 1985), or greater cation accumulation within the peat rather than decreased cation retention efficiency of the peatland.

What factors account for the differential retention of cations (Table II) observed in the S-2 peatland? Previous studies have attributed the greater retention of $\mathrm{Ca}$ relative to $\mathrm{Mg}$ either to the higher affinity of Ca for ion exchange sites (Damman, $1987,1986)$ or to the ratio of inputs (Chapman, 1964; Malmer, 1988). In the Marcell bog, the Ca:Mg molar ratio in the peat (2.4) is intermediate between that in precipitation (2.6-3.3; Table I) and that in upland runoff (2.1). Ion exchange would be expected to enhance the $\mathrm{Ca}: \mathrm{Mg}$ ratio in the peat to a value above that found in the bog waters (1.6 average ratio in outflow) by a factor of 1.5-2.0 (Weber, 1972). An enhancement of 1.5 is observed (2.4/1.6) in accordance with this prediction. However, it is the much greater incorporation of $\mathrm{Ca}$ (relative to $\mathrm{Mg}$ ) into woody biomass (Table III) that lowers the ratios in the bog waters and peat below the ratio of the inputs. Although both ion exchange and incorporation into woody biomass contribute to the selective retention of $\mathrm{Ca}$, storage in woody biomass is quantitatively more important.

It is more difficult to explain the relative retentions of $\mathrm{Mg}, \mathrm{K}$ and $\mathrm{Na}$. It is noteworthy that neither $\mathrm{Na}$ nor $\mathrm{Cl}$ (data not shown) is conservative within the peatland (cf. Damman, 1986); both are retained primarily in the peat rather than in plant biomass (Table III). The fact that only $\mathrm{Na}$ showed increased export even though all cations may have experienced an increase in inputs may indicate that $\mathrm{Na}$ retention capacity is more limited than that for other cations. Were cation exchange the only mechanism of retention, a greater retention of $\mathrm{Mg}$ would be expected relative to $\mathrm{Na}$; in fact, the retention efficiencies are similar or may even favor $\mathrm{Na}$ (Table II). Evidently a mechanism other than ion exchange exists for binding of $\mathrm{Na}$ within the organic matter of peat. Such a mechanism for binding of $\mathrm{K}$ is well known; $\mathbf{K}$ is actively taken up by living plant tissues such that concentrations in surface moss are much higher than in peat (e.g., Malmer, 1962; Chapman, 1964; Damman, 1986, 1978). This is reflected in the high uptake rates of $\mathrm{K}$ by the vegetation (especially by bryophytes; Table III) and the high ratio of the pool in vegetation to the pool in peat $(0.12$ for $\mathrm{K}$ vs. 0.002 for $\mathrm{Na}, 0.02$ for $\mathrm{Mg}$, and 0.06 for $\mathrm{Ca}$. This concentration in the vegetation makes the estimated accumulation within the peatland sensitive to small errors in both concentrations and biomass accretion rates. The discrepancy between estimated accumulation rates in the peatland and 
the retention based on the mass balance (Table III) may result from such errors. Alternatively, the discrepancy may reflect the highly variable retention efficiency of the peatland for K (Table II); a longer record of inputs and outputs may be needed to accurately estimate the retention. The accumulation in moss and green tissues of vascular plants may render the peatland similarly susceptible to frostinduced mobilization as observed in the upland; this mobilization mechanism might contribute to the highly variable retention efficiency for $\mathrm{K}$. Based on the six years of measurements, it appears that retention of all cations is lowest in years with low inputs from upland runoff; failure to regenerate ion exchange sites $(\mathrm{Ca}, \mathrm{Mg}, \mathrm{Na})$ or labile pools in vegetation $(\mathrm{K})$ in spring does not prevent leaching from such sites in summer, but does result in low retention efficiency or even a net export. This confirms the importance of upland runoff as a nutrient source for perched bogs (Buttleman and Grigal, 1985; Grigal, 1991).

\section{Summary and Conclusions}

Long-term monitoring of the Marcell S-2 peatland was used to evaluate trends in atmospheric deposition, responses of the peatland to vegetation growth dynamics, and mechanisms of cation retention. The data suggest that an increase in dry deposition of all cations may have occurred in this interval, although wet-only and dry bucket collectors failed to record such an increase. Despite widely varying annual inputs of cations to the peatland in response to variations in annual snowfall and upland runoff, the export of cations from the peatland remained nearly constant. Export of $\mathrm{Na}$ has increased steadily since 1971, possibly in response to increase atmospheric deposition. In drought years, retention of all cations was enhanced; if enhanced decomposition of peat occurs in such summers, the released cations are efficiently retained on ion exchange sites in the peat. This ion exchange reservoir was shown to be important for seasonal and annual buffering of cation export from the peat. Despite the magnitude of the reservoir of cations on ion exchange sites, the process of ion exchange generates little acidity in this peatland on an annual basis. Storage of cations (primarily $\mathrm{Ca}$ ) in woody biomass is quantitatively more important than ion exchange in this forested peatland.

\section{Acknowledgment}

This work was funded by NSF (Grant No. DEB 7922142).

\section{References}

Andrus, R. E.: 1986, 'Some Aspects of Sphagnum Ecology', Can. J. Bot. 64, 416-426.

Baas Becking, L. G. M. and Nicolai, E.: 1934, Blumea 1, 10. 
Baker, L. A.: 1991, 'Regional Estimates of Atmospheric Dry Deposition', in D. F. Charles (ed.), Acidic Deposition and Aquatic Ecosystems, Regional Case Studies, Springer-Verlag, New York, pp. 645-652.

Baker, L. A., Eilers, J. M., Cook, R. B., Kaufmann, P. R. and Herlihy, A. T.: 1991, 'Interregional Comparison of Surface Water Chemistry and Biogeochemical Processes', in D. F. Charles (ed.), Acidic Deposition and Aquatic Ecosystems: Regional Case Studies, Springer-Verlag, New York, pp. 567-614.

Bayley, S. E., Behr, R. S., and Kelly, C. A.: 1986, 'Retention and Release of S from a Freshwater Wetland', Water, Air, and Soil Pollut. 31, 101-114.

Bayley, S. and Schindler, D. W: 1987, 'Sources of Alkalinity in PreCambrian Shield Watersheds under Natural Conditions and After Fire or Acidification', in T. C. Hutchinson and K. Meema (eds.), Effects of Air Pollutants on Forests, Wetlands \& Agriculture, Springer-Verlag, Berlin, pp. 531-548.

Bayley, S. E., Vitt, D. H., Newbury, R. W., Beaty, K. G., Behr, R. and Miller, C.: 1987, 'Experimental Acidification of a Sphagnum-Dominated Peatland: First year Results,' Can. J. Fish. Aquat. Sci. 44, 194-205.

Bellamy, D. J. and Rieley, J.: 1967, 'Some Ecological Statistics of a "Miniature Bog", Oikos 18, $33-40$.

Boatman, D. J., Hulme, P. D. and Tomlinson, R. W.: 1975, 'Monthly Determinations of Sodium, Potassium, Magnesium, and Calcium in the Rain and in Pools on the Silver Flowe, National Nature Reserve, England', J. Ecol. 63, 903-912.

Buttleman, C. G. and Grigal, D. F.: 1985, 'Use of the Rb/k Ratio to Evaluate Potassium Nutrition of Peatlands', Oikos 44, 253-256.

Cawse, P. A.: 1974, A Survey of Atmospheric Trace Elements in the U.K., AERE Harwell Report R 7669 , London.

Chapman, S. B.: 1964, 'Ecology of Coam Rigg Moss, Northamberland. II. the Chemistry of Peat Profiles and the Development of the Bog System', J. Ecol. 52, 315-321.

Clymo, R. S.: 1963, 'Ion Exchange in Sphagnum and its Relation to Bog Ecology', Ann. Bot. 27, 309-324.

Clymo, R. S.: 1964, 'The Origin of Acidity in Sphagnum bogs', The Bryologist 67, 427-431.

Clymo, R. S.: 1967, 'Control of Cation Concentrations and in Particular of pH, in Sphagnumdominated Communities', in H. L. Golterman and R. S. Clymo (eds.), Chemical Environment in the Aquatic Habitat, N. V. Noord-Hollandsche Uitgevers Maatschappij, Amsterdam, pp. 273284.

Clymo, R. S.: 1987, 'Interactions of Sphagnum with Water and Air', in T. C. Hutchinson and K. M. Meema (eds.), Effects of Atmospheric Pollutants on Forests, Wetlands and Agricultural Ecosystems, Springer-Verlag, Berlin, pp. 513-529.

Comeau, P. L. and Bellamy, D. J.: 1986, 'An Ecological Interpretation of the Chemistry of Mire Waters from Selected Sites in Eastern Canada', Can J. Bot 64, 2576-2581.

Cronan, C. S. and Reiners, W. A.: 1983, 'Canopy Processing of Acidic Precipitation by Coniferous and Deciduous Forests in New England, U.S.A.', Oecologia 59, 216-223.

Damman, A.: 1978, 'Distribution and Movement of Elements in Ombrotrophic Peat Bogs', Oikos 30, $480-495$.

Damman, A. W. H.: 1986, 'Hydrology, Development, and Biogeochemistry of Ombrogenous Peat Bogs with Special Reference to Nutrient Relocation in a Western Newfoundland Bog', Can. J. Bot. 64, 384-394.

Damman, A. W. H.: 1987, "Variation in Ombrotrophy: Chemical Differences Among and within Ombrotrophic Bogs', Proc. Symp. Welands and Peatlands, Internat. Peat Soc., Edmonton, Canada, pp. 85-93.

Davidson, C. I. and Elias, R. W.: 1982, 'Dry Deposition and Resuspension of Trace Elements in the Remote High Sierra', Geophys. Res. Lett. 9, 91-93.

Devito, K. J., Dillon, P. J., and LaZerte, B. D.: 1989, 'Phosphorous and Nitrogen Retention in Five Precambrian Shield Watersheds', Biogeochem. 8, 185-204. 
Driscoll, C. T., Likens, G. E., Hedin, L. O., Eaton, J. S. and Bormann, F. H.: 1989, 'Changes in the Chemistry of Surface Waters. Twenty-Five year Results at the Hubbard Brook Experimental Forest, NH.', Environ. Sci. Technol. 23, 137-156.

Eisenreich, S. J., Hollod, G. J. and Langevin, S.: 1978, Precipitation Chemistry and Atmospheric Deposition of Trace Elements in Northeastern Minnesota. Minnesota Envir. Qual. Council., Minneapolis.

Eisenreich, S. J., Rapaport, R., Urban, N., Capel, P., Looney, B. and Baker, J.: 1984, 'Accumulation and Processing of Chlorinated Hydrocarbons in Lake and Bog Sediments: Relationship to Atmospheric Deposition', in Proceedings Workshop Paleolimnological Studies of History and Effects of Acidic Precipitation, U.S.EPA Rep. CR-811631-01, Washington, D.C.

Engstrom, D. R.: 1987, 'Influence of Vegetation and Hydrology on the Humus Budgets of Labrador Lakes, Canada', Can. J. Fish. Aquat. Sci. 44, 1306-1314.

Gies, T. and Loetschert, W.: 1973, 'Investigations on the Cation Content in a Bog. Part 2. Seasonal Changes and the Influence of Sphagnum Vegetation', Flora 162, 244-268.

Glaser, P. H. and Janssens, J. A.: 1986, 'The Bryophyte Flora and Major Peat-Forming Mosses at Red Lake Peatland, Minnesota, U.S.A.', Can. J. Bot. 64, 427-442.

Glime, J. M., Wetzel, R. G. and Kennedy, B. J.: 1982, 'The Effects of Bryophytes on Succession from Alkaline Marsh to Sphagnum Bog,' Amer. Midl. Natur. 108, 209-223.

Gore, A. J. and Allen, S. E.: 1956, 'Measurement of Exchangeable and Total Cation Content for $\mathrm{H}^{+}$, $\mathrm{Na}^{+}, \mathrm{K}^{+}, \mathrm{Mg}^{2+}, \mathrm{Ca}^{2+}$ and Iron in High Level Blanket Peat', Oikos 7, 48-55.

Gorham, E., Bayley, S. E. and Schindler, D. W.: 1984, 'Ecological Effects of Acid Deposition Upon Peatlands: A Neglected Field in “Acid Rain" Research', Can. J. Fish.Aquat, Sci. 41, 1256-1268.

Gorham, E., Underwood, J. K., Martin, F. B. and Ogden, J. G.: 1986, 'Natural and Anthropogenic Causes of Lake Acidification in Nova Scotia, Canada', Nature 324, 451-453.

Gorham, E., Wheeler, G. A., Janssens, J. A. and Glaser, P. H.: 1987, 'The Natural and Anthropogenic Acidification of Peatlands: An Overview', in T. C. Hutchinson and K. Meema (eds.), Effects of Air Pollutants on Forests Agriculture, and Wetlands, Springer-Verlag, Berlin, pp. 493-512.

Gravenhorst, G., Hofken, K. D. and Georgii, H. W.: 1983, 'Acidic Input to a Beech and Spruce Forest', in S. Beilke and A. J. Elshoot (eds.), Acid Deposition, D. Reidel Publ. Co., Boston, pp. 155-171.

Grigal, D. F.: 1985, 'Sphagnum Production in Forested Bogs of Northern Minnesota,' Can. J. Bot. 63, $1204-1207$.

Grigal, D. F.: 1991, 'Elemental Dynamics in Forested Bogs in Northern Minnesota,' Can. J. Bot. 69, 539-546.

Grigal, D. F., Buttleman, C. G. and Kernik, L. K.: 1985, 'Biomass and Productivity of the Woody Strata of Forested Bogs in Northern Minnesota,' Can. J. Bot. 63, 2416-2424.

Hedin, L. O., Granat, L., Likens, G. E., Buishand, T. A., Galloway, J. N., Butler, T. J. and Rodhe, H.: 1994, 'Steep Declines in Atmospheric Base Cations in Regions of Europe and North America,' Nature 367, 351-354.

Hemond, H.: 1980, 'Biogeochemistry of Thoreaus's Bog, Concord, Massachusetts,' Ecol. Monogr. 50, 507-526.

Henderson, G. S., Harris, W. F., Rodd, D. and Grizzard, T.: 1977, 'Quantity and Chemistry of Throughfall as Influenced by Forest type and Season,' J. Ecol. 65, 365-374.

Henrot, J. and Wieder, R. K.: 1990, 'Processes of Iron and Manganese Retention in Laboratory Peat Microcosms Subjected to Acid Mine Drainage,' J. Environ. Qual. 19, 312-320.

Johnston, C. A. Bubenzer, G. D., Lee G. B., Madison, F. W. and McHenry, J. R.: 1984, 'Nutrient Trapping by Sediment Deposition in a Seasonally Flooded Lakeside Wetland,' J. Environ. Qual. 13, 283-290.

Johnston, C. A., Detenbeck, N. E. and Niemi, G. J.: 1990, 'The Cumulative Effect of Wetlands on Stream Water Quality and Quantity - A Landscape Approach,' Biogeochem. 10, 105-141.

Kilham, P.: 1982, 'Acid Precipitation - Its Role in the Alkalization of a Lake in Michigan, U.S.A.,' Limnol. Oceanogr. 27, 856-857.

Kirchner, J. W.: 1992, 'Heterogeneous Geochemistry of Catchment Acidification,' Geochim. Cosmochim. Acta 56, 2311-2327. 
LaZerte, B.: 1993, 'The Impact of Drought and Acidification on the Chemical Exports from a Minerotrophic Conifer Swamp,' Biogeochem. 18, 153-175.

Lindberg, S. E., and Lovett, G. M.: 1983, 'Application of Surrogate Surface and Leaf Extraction Methods to Estimation of Dry Deposition to Plant Canopies,' in H. R. Pruppacher, R. G. Semonin and W. G. Slinn, (eds.), Precipitation Scavenging, Dry Deposition, and Resuspension, Elsevier, London, pp. 837-848.

Lindberg, S. E., Lovett, G. M., Richter, D. D. and Johnson, E. W.: 1986, 'Atmospheric Deposition and Canopy Interactions of Major Ions in a Forest,' Science 231, 141-145.

Lovett, G. M., and Lindberg, S. E.: 1984, 'Dry Deposition and Canopy Exchange in a Mixed Oak Forest as Determined by Analysis of Throughfall,' J. Appl. Ecol. 21, 1013-1028.

Malmer, N.: 1962, 'Studies on Mire Vegetation in the Archaean Area of Southwestern Gotaland (South Sweden). I. Vegetation and Habitat Conditions on the Akholt Mire,' Opera Botanica 7, $1-322$.

Malmer, N.: 1988, 'Patterns in the Growth and the Accumulation of Inorganic Constituents in the Sphagnum Cover on Ombrotrophic Bogs in Scandinavia,' Oikos 53, 105-120.

Mayer, R., and Ulrich, B.: 1982, 'Calculation of Deposition Rates from the Flux Balance and Ecological Effects of Atmospheric Deposition upon Forest Ecosystems', in H. W. Georgii and J. Pankrath (eds.), Deposition of Atmospheric Pollutants, P. Reidel Publ. Co., Boston, pp. 195-200.

McKnight, D., Thurman, E. M., Wershaw, R. and Hemond, H.: 1985, 'Biogeochemistry of Aquatic Humic Substances in Thoreau's Bog, Concord, Massachusetts,' Ecology 66, 1339-1352.

Metzer, N. A.: 1986, Trace-Metal Chemistry of Wet-only Precipitation in Rural and Urban Minnesota, M. S. Thesis, Univ, of Minnesota, Minneapolis.

Munger, J. W. and Eisenreich, S. J.: 1983, 'Continental-Scale Variations in Precipitation Chemistry,' Environ. Sci. Tech. 17, 32A-42A.

Nilsson, S. I., Miller, H. G. and Miller, J. D.: 1982, 'Forest Growth as a Possible Cause of Soil and Water Acidification: An Examination of the Concepts,' Oikos 39, 40-49.

Puustjarvi, V.: 1957, Acta Agriculturae Scand. 7, 190.

Reader, R. J. and Stewart, J. M.: 1972, 'The Relationship Between Net Primary Production and Accumulation for a Peatland in Southeastern Manitoba,' Ecology 53, 1024-1037.

Rohbock, E.: 1982, 'Atmospheric Removal of Airborne Metals by Wet and Dry Deposition,' in H. W. Georgii and J. Pankrath (eds.), Deposition of Atmospheric Pollutants. D. Reidel Publ. Co. Boston, pp. 159-171.

Santelmann, M. V. and Gorham, E.: 1988, 'The Influence of Airborne Road Dust on the Chemistry of Sphagnum Mosses,' J. Ecol 76, 1219-1231.

Siegel, D. I.: 1983, 'Ground Water and the Evolution of Patterned Mires, Glacial Lake Agassiz Peatlands, Northern Minnesota, U.S.A.,' J. Ecol. 71, 913-922.

Sjoers, H.: 1950, 'On the Relation Between Vegetation and Electrolytes in North Swedish Mire Waters,' Oikos 2, 241-258.

Skene, M.: 1915, 'The Acidity of Sphagnum and its Relation to Chalk and Mineral Salts,' Ann Bot. $29,65-87$.

Skiba, U., Cresser, M. S., Derwent, R. G. and Futty, D. W.: 1989, 'Peat Acidification in Scotland,' Nature 337, 68-70.

Small, E.: 1972, 'Ecological Significance of Four Critical Elements in Plants of a Raised Sphagnum Peat Bog,' Ecology 53, 498-503.

Tilton, D. L. and Kadlec, R. H.: 1979, 'The Utilization of a Freshwater Wetland for Nutrient Removal from Secondarily Treated Waste Water Effluent,' J. Environ. Qual. 8, 328-334.

Timmons, D. R., Verry, E. S., Burwell, R. E. and Holt, R. F.: 1977, 'Nutrient Transport in Surface Runoff and Interflow from an Aspen Birch Forest,' J. Environ. Qual. 6, 188-192.

Urban, N. R.: 1987, The Nature and Origins of Acidity in Bogs, Ph.D. Thesis, Univ. Minnesota, Minneapolis.

Urban, N. R. and Bayley, S. E.: 1986, 'The Acid-Base Balance of Peatlands: A Short-Term Perspective,' Water, Air, and Soil Pollut. 30, 791-800.

Urban, N. R. Bayley, S. E. and Eisenreich, S. J.: 1989a, 'Export of Dissolved Organic Carbon and Acidity from Peatlands,' Water Resourc. Res. 25, 1619-1628. 
Urban, N. R. and Eisenreich, S. J.: 1988, 'Nitrogen Cycling in a Forested Minnesota Bog,' Can. J. Bot. 66, 435-449.

Urban, N. R., Eisenreich, S. J. and Bayley, S. E.: 1989c, 'The Relative Importance of Denitrification and Nitrate Assimilation in Midcontinental Bogs,' Limnol. Oceanogr. 33, 1611-1617.

Urban, N. R., Eisenreich, S. J. and Gorham, E.: 1987, 'Proton Cycling in Bogs: Geographic Variation in Northeastern North America,' in T. C. Hutchinson and K. M. Meema (eds.), The Effects of Air Pollutants on Forests, Wetlands and Agricultural Ecosystems, Springer-Verlag, Berlin, pp. 577-598.

Urban, N. R., Eisenreich, S. J. and Grigal, D. F.: 1989b, 'Sulfur Cycling in a Forested Sphagnum Bog in Northern Minnesota, U.S.A.,' Biogeochem. 7, 81-110.

Urban, N. R., Eisenreich, S. J., Grigal, D. F. and Schurr, K. T.: 1990, 'Mobility and Diagenesis of Pb and $\mathrm{Pb}-210$ in Peat,' Geochim. Cosmochim. Acta 54, 3329-3346.

van der Valk, A. G., Davis, C. B., Baker, J. L. and Beer, C. E.: 1978, 'Natural Freshwater Wetlands as Nitrogen and Phosphorus Traps for Land Runoff,' in P. E. Greeson, J. R. Clark and J. E. Clark (eds.), Wetland Functions and Values: The State of our Understanding, Amer. Water Res. Assoc., Minneapolis, pp. 457-467.

Verry, E. S.: 1975, 'Streamflow Chemistry and Nutrient Yields from Upland-Peatland Watersheds in Minnesota,' Ecology 56, 1149-1157.

Verry, E. S.: 1983, 'Precipitation Chemistry at the Marcell Experimental Forest in North Central Minnesota,' Water Resourc. Res. 19, 454-462.

Verry, E. S.: 1984, 'Microtopography and Water Table Fluctuation in a Sphagnum Mire', in Proceedings of The 7th Internat. Peat Congress, Irish National Peat Committee Dublin, pp. 11-31.

Verry, E. S., Brooks, K. N. and Barten, P. K.: 1988, 'Streamflow Response from an Ombrotrophic Mire', in Symp. Hydrology of Wetlands in Temperate and Cold Regions, Joensuu, Finland, Publ. Acad. Finland, Helsinki, pp. 52-59.

Verry, E. S. and Timmons, D. R.: 1977, 'Precipitation Nutrients in the Open and Under Two Forests in Minnesota,' Can. J. For. Res. 7, 112-119.

Verry, E. S. and Timmons, D. R.: 1982, 'Waterborne Nutrient Flow Through an Upland-Peatland Watershed in Minnesota,' Ecol. 63, 1456-1467.

Verry, E. S. and Urban, N. R.: 1992, 'Nutrient Cycling at Marcell Bog, Minnesota,' Suo 43, 147-153.

Vitt, D. H. and Slack, N. G.: 1975, 'An Analysis of the Vegetation of Sphagnum-Dominated KettleHole Bogs in Relation to Environmental Gradients,' Can. J. Bot. 53, 332-359.

Weber, W. J.: 1972, Physicochemical Processes for Water Quality Control, John Wiley \& Sons, New York. 